\title{
RAZVOJNI POLOŽAJ GORENJSKE STATISTIČNE REGIJE
}

\author{
dr. Simon Kušar, dr. Andrej Černe \\ Oddelek za geografijo, Filozofska fakulteta Univerze v Ljubljani \\ Aškerčeva 2, SI-I000 Ljubljana \\ e-mail: simon.kusar@ff.uni-lj.si, andrej.cerne@ff.uni-lj.si \\ Izvirni znanstveni članek \\ COBISS 1.01 \\ DOI: 10.4312/dela.41.3.55-79
}

\section{Izvleček}

Članek je namenjen opredeljevanju regionalne strukture na podlagi sistema izbranih kazalcev, ki smo jih uporabili za oceno relativnega razvojnega položaja Gorenjske statistične regije. Izbrani postopek (standardizacija, rangiranje) je kot eden izmed elementov možnega vrednotenja regionalnih razvojnih potencialov namenjen opredeljevanju primerjalnih prednosti regij v regionalnem razvojnem kontekstu.

Ključne besede: Gorenjska statistična regija, Slovenija, regionalna struktura, sistem regionalnih kazalcev, standardizacija, rangiranje

\section{DEVELOPMENTAL CONDITION OF GORENJSKA STATISTICAL REGION}

\begin{abstract}
The aim of the article is to define the regional structure by the system of selected indicators, which were applied for the evaluation of the relative developmental condition of Gorenjska statistical region in Slovenia. Methodological approach (standardization, ranking) as one of the elements of possible evaluation of regional development potentials was applied for the evaluation of comparative regional opportunities within the context of regional development.
\end{abstract}

Key words: Gorenjska statistical region, Slovenia, regional structure, the system of regional indicators, standardization, ranking 


\section{UVOD}

Velika raznolikost/raznovrstnost in kompleksnost regionalnega razvoja vpliva na številne možne vidike njegovega opredeljevanja. Državna in družbena moč ter moč kapitala in politična moč neposredno in posredno vplivajo na gospodarski in življenjski prostor na različnih prostorskih ravneh: na ravni države, province (regije), okrožja (občine), mesta, soseske in gospodinjstva, hkrati pa tudi na ravni nadnacionalne skupnosti in na ravni zvez ter regionalnih združenj. Razvoj je strukturiran s tržnimi razmerji in opredeljen z lokacijami in medsebojnimi tokovi kapitala, blaga, dela in informacij. Regije so nastale z različnimi medsebojno delujočimi procesi, ki so vplivali na njihov nastanek v različnih obdobjih. Njihov značaj je izredno kompleksen, število spremenljivk je lahko zelo veliko in najpogosteje so v razmeroma tesni povezanosti in soodvisnosti. Regionalne strukture in regionalnih funkcij ne moremo opredeljevati na podlagi nepopolnih in hkrati preštevilnih podatkov. Pomisleki o ocenjevanju regionalnega razvoja obstajajo samo, dokler ne opredelimo vloge oziroma pomena razvoja, njegovega bistva in predmeta ter tudi samega procesa razvoja. Poleg tega regije vsebujejo, kot je zapisal Braudel (1991), še pripovedi, opise in podobe.

Med splošne cilje razvoja nedvomno sodijo enakost, kakovost življenja in okolja, možnost izbire, zdravje in varnost, učinkovitost in izvedljivost. Kakovost življenja je cilj, ki izraža neekonomske, manj kvantificirane kategorije splošne blaginje skupnosti. Zdravje in varnost se nanašata na nevarnosti za zdravje in promocijo fizične in emocionalne blaginje. Učinkovitost in izvedljivost sta cilja, ki se nanašata na razvojna merila. Razvojne razlike se, ne nazadnje, nanašajo na neenakosti med ljudmi z vidika materialnih dobrin, na regionalne neenakosti, ki se kažejo v obliki geografskih entitet, v katerih so prebivalci ene regije v povprečju bolj bogati kakor v drugi, ter na družbene neenakosti, ki kažejo, da v entitetah živijo, ne glede na povprečno bogastvo, bogati in revni (PierreNoël, 2006). Kaj je stvarni značaj razvoja in kako lahko različni koncepti in teorije prispevajo k boljšemu razumevanju razvojnega procesa, je vprašanje, na katerega še nimamo ustreznih odgovorov.

Pri regionalnih analizah lahko uporabljamo zelo različne pristope in sisteme kazalcev ter meril, ki so velikokrat odvisni od namena in ciljev analiz. Novi koncepti blaginje, ki so usmerjeni v človeka in družbo kot celoto, upoštevajo poleg razvoja na področju zagotavljanja materialnega standarda še napredke na drugih področjih družbene blaginje, tako na globalni, nadnacionalni, nacionalni kot tudi na regionalni ravni (Milanović, 2006). Ekonomija skupne blaginje temelji na človeškem dostojanstvu, solidarnosti, ekološki trajnosti, družbeni pravičnosti, demokratičnem soodločanju in transparentnosti. Indeks človekovega razvoja (dolžina človekovega življenja, znanje, življenjski standard), s katerim merimo družbene, socialne in okoljske značilnosti družbe, je širši pristop k razumevanju razvoja. Kazalniki blaginje v Sloveniji (Kazalniki blaginje v Sloveniji, 2014) so zgrajeni na podlagi kazalnikov materialne (6 vodilnih in 27 dopolnilnih), družbene (7 vodilnih in 33 dopolnilnih) in okoljske blaginje (7 vodilnih in 25 dopolnilnih), skupaj torej na 92 kazalnikih.

Vplivi regionalnega razvoja na socialni, gospodarski in prostorski razvoj se nanašajo na gospodarsko rast, ustvarjanje delovnih mest, kakovost življenja, kakovost 
naravnega okolja in oskrbo s storitvami. V kontekstu kohezijske politike so kazalci operativnih programov opredeljeni glede na njihove razvojne prioritete, oziroma posamezna razvojna področja: konkurenčnost podjetij in raziskovalna odličnost, gospodarsko-razvojna infrastruktura, povezovanje naravnih in kulturnih potencialov, razvoj regij, tehnična pomoč (Kavaš, 2010; NSRO, 2008). Urad za makroekonomske analize in razvoj (UMAR) objavlja v delovnih zvezkih z regionalno tematiko celovito predstavitev slovenskih regij na podlagi različnih socio-ekonomskih podatkov in kazalcev. Tako je npr. indeks razvojne ogroženosti (od 2000 dalje) namenjen določanju indikativnega obsega neposrednih regionalnih spodbud in opredeljevanju prednostnih območij za dodeljevanje regionalnih spodbud kot podlagi za razdelitev posrednih regionalnih spodbud po regionalnem merilu. Zasnovan je na podlagi šestih skupin kazalcev: regionalni razvitosti (BDP na prebivalca, osnova za dohodnino na prebivalca, razmerje med delovnimi mesti in delovno aktivnim prebivalstvom), prebivalstvu (indeks staranja), trgu dela (stopnja regionalne zaposlenosti), izobrazbi (povprečno število let šolanja), okolju (priključenost na javno kanalizacijo) in krajini (delež območij Natura $2000 \mathrm{v}$ skupni površini) (Pečar, Kavaš, 2006).

Regionalne statistike (Eurostatove zbirke podatkov General and regional statistics, Regions and cities) merijo 'razvitost', ki je tudi podlaga za ukrepanje na področju nadnacionalnih in nacionalnih regionalnih politik. Razlike med regijami so pogosto opredeljene v obliki razkoraka v stopnji gospodarske razvitosti, razlik v socialno-gospodarski strukturi, razkoraka med specifičnimi količinskimi in/ali kakovostnimi kazalci oziroma skupinami kazalcev, ki so zasnovani na podlagi odstopanj od nacionalnega ali regionalnega povprečja, določanja aritmetičnega povprečja in standardnih odklonov, agregiranja kazalcev na ravni lokalne skupnosti ter, ne nazadnje, tudi razmerij med najvišjimi in najnižjimi vrednostmi za posamezne kazalce. Pri tem uporabljamo različne metode. Primerjava regij na podlagi skrajnih vrednosti kaže, kolikokrat je BDP na prebivalca v regiji z najvišjim BDP na prebivalca večji v primerjavi z regijo z najmanjšim BDP na prebivalca, ne kaže pa razmerij do ostalih regij. Eden izmed načinov za merjenje regionalnih razlik v BDP na prebivalca je Ginijev koeficient neenakosti, merilo neenakosti porazdelitve določenega pojava. Razpršenost BDP na prebivalca meri odstopanja od državnega povprečja v vseh regijah, tehtano s številom prebivalcev po regijah. Razpoložljiv dohodek gospodinjstev po regijah je informacija o dejanskem dohodku prebivalstva regij (Pečar, 2012).

$\mathrm{Z}$ metodološkega vidika smo se pri opredeljevanju razvojnega položaja Gorenjske statistične regije odločili za uporabo primerjalne analize. Namenjena je vpogledu v regionalno strukturo in funkcije regije z vidika njenega relativnega položaja in na tej podlagi oceni stanja in možnega nadaljnjega opredeljevanja vprašanj razvoja regije.

\section{PRISTOP}

\section{I. Primerjalna analiza}

Primerjalna analiza, s katero smo želeli opredeliti razvojni položaj Gorenjske statistične regije, je bila narejena s pomočjo standardizacije podatkov in računanja rangov. 
- Standardizacija. Kazalce smo standardizirati glede na njihov značaj (preračuni na število prebivalcev v regiji oziroma površino regije - 1000 prebivalcev oz. $\mathrm{km}^{2}$; število delovno aktivnega prebivalstva, število gospodarjev-upraviteljev kmetijskih gospodarstev, ipd.), razen tiste, ki že kažejo razmerja in omogočajo medsebojno primerjavo brez vpliva absolutne vrednosti.

- Rangiranje. Po standardizaciji smo vsak kazalec po regijah razvrstili/rangirali od 1-12. Z rangom 12 je ocenjena regija, ki je pri posameznem kazalcu najbolje uvrščena. Pri nekaterih kazalcih smo razvrstili/rangirali inverzno, saj z vidika trajnostnega regionalnega razvoja manjše vrednosti pomenijo bolj ugodno strukturo (npr. število brezposelnih je z vidika regionalnega razvoja ugodnejše, če je čim manjše). Nekatere kazalce je bilo težko opredeliti kot $\mathrm{v}$ celoti pozitivne oziroma negativne.

- Seštevanje rangov. Range znotraj posamezne skupine kazalcev (socio-ekonomska struktura, raba zemljišč ...) smo sešteli za vsako regijo. Izračun povprečnih in končnih rangov omogoča medsebojno primerjavo med regijami znotraj posamezne skupine kazalcev in med skupinami (končno rangiranje).

- Primerjava izbranih kazalcev. Na podlagi izbranih kazalcev smo primerjali razvojni položaj Gorenjske statistične regije z ostalimi statističnimi regijami v Sloveniji. Rezultat je pokazal, kakšen je položaj Gorenjske statistične regije znotraj posamezne skupine kazalcev, z izračunom povprečnega ranga skupin kazalcev pa smo izračunali tudi končni povprečni rang, ki je bil osnova za končno rangiranje statističnih regij.

V tem kontekstu je potrebno opozoriti na nekatere vsebinske in metodološke omejitve primerjalne analize, predvsem $\mathrm{z}$ vidika primerjave med različnimi prostorskimi enotami, oziroma regijami kot svojstvenimi družbenimi, gospodarskimi in prostorskimi enotami, z enkratno kombinacijo razmerij med različnimi dejavniki regionalnega razvoja.

Primerjalna analiza vključuje štiri medsebojno povezane vsebine: regionalno strukturo, dejavnike, pojave in procese, ki so vplivali na strukturo in funkcijo regije, ter težnje oziroma možnosti prihodnjega regionalnega razvoja. Izhaja iz strukturiranja opisa stanja v posameznih sestavinah regionalnega razvoja, torej iz spoznanih dejstev, brez vrednostnih sodb. Nanaša se na številne gospodarske, socialne in prostorske dejavnike, ki so vplivali na spreminjanje strukture in funkcije regije, in lahko predstavljajo tudi pomembne dejavnike prihodnjih regionalnih razmer. Regionalna vprašanja niso vprašanja disciplin, marveč vprašanja usmerjanja, spreminjanja posameznih pojavov in procesov, oziroma razvojnih teženj v skladu z možnimi cilji prihodnjega regionalnega razvoja. Pri opredeljevanju relativnega položaja regije gre torej za poskus združevanja, oziroma povezovanja družbenih vrednot s spremembami regionalne strukture in funkcije, razmerij med dejavniki, pojavi in procesi regionalnega razvoja, ki vplivajo na spremembo relativnega položaja regij.

Primerjalna analiza je usmerjena $\mathrm{v}$ opredeljevanje relativnega položaja regije na podlagi razlik v specifičnih regionalnih razmerah, ne pa skupnih regionalnih značilnosti. Pomembne so torej razlike med regijami in ne skupne poteze. Hkrati izhaja analiza iz razlik samih po sebi, ne pa iz njihovega pomena. Kazalci, ki jih uporabljamo pri primerjalni analizi, pomagajo opisati obstoječa dejstva, razmere in pogoje brez stališč in mnenj o 
tem, zakaj so ti pogoji oziroma razmere pomembne. Primerjalna analiza izhaja iz dejstev, procesov in teženj posameznih elementov regionalnega razvoja. Dejstva govorijo o stanju, procesi in pojavi o preteklosti, težnje o možni prihodnosti. Primerjalna analiza torej ni namenjena spoznavanju pomena raznovrstnih pojavov in procesov, ki so privedli oziroma vplivali na regionalno strukturo in funkcijo, ter njihovih razvojnih posledic in ne vsebuje razlag strukture in funkcije regije, niti ne podaja odgovorov za iskanje poti pri reševanju regionalnih razvojnih vprašanj.

\subsection{Sistem kazalcev za merjenje regionalnega razvoja}

Za oceno razvojnega položaja Gorenjske statistične regije smo se pri primerjalni analizi oprli na rezultate mednarodne študije CONSPACE (Černe, Gulič, Kušar, 2004). Sistem izbranih kazalcev regionalnega razvoja smo uporabili za oceno regionalne strukture vseh statističnih regij v Sloveniji, saj smo le tako lahko opredelili relativni razvojni položaj Gorenjske statistične regije. S kazalci, razvrščenimi v 10 skupin, smo opisali regionalno strukturo na podlagi opredeljevanja demografske in socialno-ekonomske strukture, mreže naselij, podeželja, kakovosti bivanja, infrastrukture, rabe zemljišč, zavarovanih območij, degradiranih in ogroženih območij (Černe, Kušar, 2006, str. 41).

Preglednica 1: Seznam CONSPACE kazalcev za vrednotenje regionalnega razvoja Table 1: The list of CONSPACE indicators for monitoring regional development

\begin{tabular}{|c|c|}
\hline Skupina kazalcev & Kazalci \\
\hline $\begin{array}{l}\text { Demografska } \\
\text { struktura }\end{array}$ & $\begin{array}{l}\text { Število prebivalcev, gostota poselitve, naravno gibanje, migracijsko gibanje } \\
\text { (posebej priseljenci), delež migracij v gibanju prebivalstva, starostne skupine } \\
\text { (otroci), starostne skupine (ostareli), starostne skupine (aktivni), število } \\
\text { gospodinjstev }\end{array}$ \\
\hline $\begin{array}{l}\text { Socio-ekonomska } \\
\text { struktura }\end{array}$ & $\begin{array}{l}\text { BDP na prebivalca, BDP na zaposlenega, struktura BDP, izdatki za raziskave in } \\
\text { razvoj, število zaposlenih v raziskavah in razvoju, nizka in visoka kvalifikacijska } \\
\text { struktura, študenti, zaposleni, aktivno prebivalstvo, zaposleni v kmetijstvu, } \\
\text { industriji in storitvah, kvalifikacijska struktura zaposlenih, dnevna migracija, } \\
\text { nezaposleni, nezaposleni (ženske), nezaposleni (mladi), nezaposleni (dolgoročna } \\
\text { nezaposlenost), zaostala, manj razvita območja }\end{array}$ \\
\hline $\begin{array}{l}\text { Poselitvena } \\
\text { struktura }\end{array}$ & $\begin{array}{l}\text { Urbana območja, funkcionalna urbana območja (FUO), prebivalstvo na gosto } \\
\text { poseljenih območjih, urbana gostota, suburbana območja, podeželska območja, } \\
\text { stopnja centralnosti, velikost urbano-podeželskih in podeželsko-urbanih migracij }\end{array}$ \\
\hline Podeželje & $\begin{array}{l}\text { Območja z nizko gostoto prebivalstva, gorska in hribovita območja, aktivno } \\
\text { kmečko prebivalstvo (starostna struktura), aktivno kmečko prebivalstvo } \\
\text { (kvalifikacijska struktura), čisti kmetje, število kmetij, velikost kmetij, ekološke } \\
\text { kmetije, dopolnilne dejavnosti na kmetijah, zaposleni v drugih dejavnostih }\end{array}$ \\
\hline $\begin{array}{l}\text { Kakovost } \\
\text { življenja }\end{array}$ & $\begin{array}{l}\text { Nova stanovanja, življenjski standard (število sob), življenjski standard }\left(m^{2} n a\right. \\
\text { prebivalca), življenjski standard (enostanovanjske hiše), kazalec zdravja, kazalec } \\
\text { varnosti, družbena participacija in integracija }\end{array}$ \\
\hline
\end{tabular}




\begin{tabular}{|c|c|}
\hline Skupina kazalcev & Kazalci \\
\hline Infrastruktura & $\begin{array}{l}\text { Število potnikov, blagovni promet, obremenitev cest, linearne povezave, prometni } \\
\text { stroški, indeks dostopnosti (središča), indeks dostopnosti (avtoceste), indeks } \\
\text { dostopnosti (nakupovalna središča), državne, regionalne in lokalne ceste } \\
\text { (gostota), državne, regionalne in lokalne ceste (novogradnja), železniško } \\
\text { omrežje (gostota), železniško omrežje (novogradnja), telefonsko omrežje, } \\
\text { mobilni telefoni, gospodinjstva z dostopom do interneta, javni dostop do } \\
\text { interneta, širokopasovne povezave, proizvodnja energije, proizvodnja električne } \\
\text { energije, poraba električne energije, poraba električne energije na zaposlenega, } \\
\text { oskrba s pitno vodo, poraba vode, količina očiščene vode, komunalni sistem, } \\
\text { odlagališča odpadkov }\end{array}$ \\
\hline Raba zemljišč & $\begin{array}{l}\text { Površina kmetijskih zemljišč, njiv, travnikov, gozdov, pašnikov, vodnih površin, } \\
\text { pozidanih zemljišč }\end{array}$ \\
\hline $\begin{array}{l}\text { Zavarovana } \\
\text { območja }\end{array}$ & $\begin{array}{l}\text { Zavarovana območja (državna, regionalna, krajinski parki, naravni parki, } \\
\text { zavarovani gozdovi, naravno okolje, kulturna dediščina), zavarovana območja } \\
\text { (Natura 2000), zavarovana kmetijska zemljišča, zavarovana vodovarstvena } \\
\text { območja, 'land care' indeks }\end{array}$ \\
\hline $\begin{array}{l}\text { Degradirana } \\
\text { območja }\end{array}$ & $\begin{array}{l}\text { Degradirana industrijska in rudarska območja, poškodovani gozdovi, onesnaženost } \\
\text { prsti, onesnaženost zraka, onesnaženost vode, onesnaženost podzemne vode }\end{array}$ \\
\hline $\begin{array}{l}\text { Ogrožena } \\
\text { območja }\end{array}$ & $\begin{array}{l}\text { Poplavna območja, plazovita in erozijska območja, območja snežnih plazov, } \\
\text { ocenjena finančna škoda zaradi naravnih nesreč }\end{array}$ \\
\hline
\end{tabular}

Opomba: Ključni, pomembni dopolnilni in raziskovalni kazalci

Vir/Source: Černe, Gulič, Kušar, 2004

V sistem CONSPACE kazalcev za merjenje regionalnega razvoja so bili vključeni 104 kazalci. Pri primerjalni analizi regij smo zaradi pomanjkanja ali nekakovostnih podatkov, neprimernosti kazalcev za standardizacijo, oziroma potrebe po dodatnih raziskavah uporabili 64 kazalcev oziroma 61,5\% v CONSPACE predvidenih kazalcev. Največ analiziranih kazalcev je bilo s področja ogroženih območij (vsi štirje kazalci), degradiranih območij (83 \% kazalcev) ter socio-ekonomskih kazalcev in rabe zemljišč (85\%). Najmanj podatkov je bilo zbranih za skupino kazalcev s področja infrastrukture (23 \%). Za nekatere kazalce ni bil uporabljen izračun, predviden v metodoloških listih, ampak je bil izbran drugačen način, ki je ustrezal naravi posameznega kazalca.

\subsection{Izračun vrednosti kazalcev}

Podatki, uporabljeni v primerjalni analizi, so se nanašali na različna leta. V analizi smo zato največkrat uporabili kazalce iz leta 2011. Pri nekaterih kazalcih to ni bil najnovejši podatek, vendar je bilo zbiranje podatkov za isto leto nujno zaradi metodološke ustreznosti primerjalne analize. Leta 2011 je bil izveden tudi registrski popis prebivalcev in gospodinjstev, zato predvidevamo, da objavljeni podatki kar v največji meri ustrezno prikazujejo dejansko stanje. 
Pri zbiranju in obdelavi podatkov so v študijskem letu 2012/2013 sodelovali študenti drugostopenjskega magistrskega študijskega programa Geografija v okviru vaj pri predmetu Metode in tehnike v regionalnem in prostorskem planiranju (nosilec prof. dr. Andrej Černe, asistent doc. dr. Simon Kušar).

Demografska struktura. V primerjalno analizo je bilo vključenih sedem od predvidenih desetih kazalcev. Treh kazalcev nismo vključili zaradi težav pri standardizaciji, ki je bila izvedena zaradi ustreznejše primerjave med statističnimi regijami. Podatki so povzeti predvsem po registrskem popisu prebivalstva iz leta 2011.

Preglednica 2: Razvojni položaj Gorenjske statistične regije - kazalci demografske strukture Table 2: Developmental condition of Gorenjska statistical region-indicators of demographic structure

\begin{tabular}{|l|l|l|}
\hline Kazalec & Izračun vrednosti kazalca & Leto podatkov \\
\hline Gostota poselitve & Število prebivalcev na km² & 2011 \\
\hline Naravno gibanje & Naravni prirastek v \%o & 2011 \\
\hline Migracijsko gibanje & Migracijski prirastek v \%o & 2011 \\
\hline Migracijsko gibanje - tuji državljani & Migracijski prirastek v \%o & 2011 \\
\hline Starostna skupina - otroci & Delež prebivalcev v starosti do 15 let & 2011 \\
\hline Starostna struktura - delovno aktivni & Delež prebivalcev v starosti 15 do 64 let & 2011 \\
\hline Starostna struktura - ostareli & Delež prebivalcev, starejših od 64 let & 2011 \\
\hline
\end{tabular}

Socio-ekonomska struktura. Podatki so bili na voljo za vse kazalce, vendar treh kazalcev nismo vključili v analizo zaradi zadreg pri njihovi standardizaciji. Podatki so povzeti iz različnih podatkovnih baz Statističnega urada Republike Slovenije, zato se leta podatkov razlikujejo.

Preglednica 3: Razvojni položaj Gorenjske statistične regije-kazalci socio-ekonomske strukture Table 3: Developmental condition of Gorenjska statistical region - indicators of socio-economic structure

\begin{tabular}{|l|l|l|}
\hline Kazalec & Izračun vrednosti kazalca & Leto podatkov \\
\hline BDP/prebivalca & BDP/prebivalca & 2010 \\
\hline Struktura BDP - storitve & Delež BDP od storitev & 2010 \\
\hline Izdatki za raziskave in razvoj & Delež BDP za raziskave in razvoj & 2010 \\
\hline $\begin{array}{l}\text { Zaposleni na področju raziskav in } \\
\text { razvoja }\end{array}$ & $\begin{array}{l}\text { Delež prebivalcev, zaposlenih na } \\
\text { področju raziskav in razvoja }\end{array}$ & 2010 \\
\hline Nizka kvalifikacijska struktura & $\begin{array}{l}\text { Delež prebivalcev brez izobrazbe, z } \\
\text { nepopolno ter s končano osnovno šolo }\end{array}$ & 2011 \\
\hline Visoka kvalifikacijska struktura & $\begin{array}{l}\text { Delež prebivalcev z visokošolsko } \\
\text { izobrazbo }\end{array}$ & 2011 \\
\hline
\end{tabular}




\begin{tabular}{|l|l|l|}
\hline Kazalec & Izračun vrednosti kazalca & Leto podatkov \\
\hline Študenti & Delež prebivalcev s statusom študenta & 2011 \\
\hline Zaposleni & Delež zaposlenega prebivalstva & 2011 \\
\hline Aktivno prebivalstvo & Delež aktivnega prebivalstva & 2011 \\
\hline Zaposleni v kmetijstvu & $\begin{array}{l}\text { Delež aktivnih prebivalcev, zaposlenih v } \\
\text { kmetijskih dejavnostih }\end{array}$ & 2011 \\
\hline Zaposleni v industriji & $\begin{array}{l}\text { Delež aktivnih prebivalcev, zaposlenih v } \\
\text { nekmetijskih dejavnostih }\end{array}$ & 2011 \\
\hline Zaposleni v storitvah & $\begin{array}{l}\text { Delež aktivnih prebivalcev, zaposlenih v } \\
\text { storitvenih dejavnostih }\end{array}$ & 2011 \\
\hline Nezaposleni & $\begin{array}{l}\text { Delež brezposelnih med aktivnim } \\
\text { prebivalstvom }\end{array}$ & 2012 \\
\hline Nezaposleni - ženske & Delež žensk med brezposelnimi & 2012 \\
\hline Nezaposleni - mladi & $\begin{array}{l}\text { Delež mladih (15-24 let) med } \\
\text { brezposelnimi }\end{array}$ & 2012 \\
\hline Dnevna migracija & Indeks delovne migracije & 2012 \\
\hline Manj razvita območja & $\begin{array}{l}\text { Povprečni rang: delež površine regije, } \\
\text { ki se uvršča med obmejna problemska } \\
\text { območja, in delež prebivalcev, ki prebiva } \\
\text { v obmejnih problemskih območjih }\end{array}$ & 2011 \\
\hline
\end{tabular}

Poselitvena struktura. Izračun vrednosti kazalcev smo izvedli s pomočjo GIS analiz. Površina urbanih in suburbanih območij je bila povzeta po kategorizaciji urbanih in suburbanih naseljih, ki jo je pripravil Statistični urad Republike Slovenije (Pregled mestnih ..., 2009). Izračuni so bili narejeni glede na administrativno mejo urbanega/ suburbanega naselja, kar pomeni, da so realni podatki nekoliko drugačni, saj administrativna območja urbanih naselij pogosto zajemajo tudi obsežnejša podeželska območja. Fukcionalna urbana območja so bila povzeta po Kušar in Pichler-Milanović (2010).

Preglednica 4: Razvojni položaj Gorenjske statistične regije - kazalci poselitvene strukture Table 4: Developmental condition of Gorenjska statistical region - indicators of settlement structure

\begin{tabular}{|l|l|l|}
\hline Kazalec & Izračun vrednosti kazalca & Leto podatkov \\
\hline Urbana območja & Delež prebivalcev v urbanih območjih & 2011 \\
\hline Funkcionalna urbana območja (FUA) & $\begin{array}{l}\text { Delež prebivalcev na funkcionalnih } \\
\text { urbanih območjih }\end{array}$ & 2011 \\
\hline Suburbana območja & Delež prebivalcev na suburbanih območjih & 2011 \\
\hline $\begin{array}{l}\text { Prebivalstvo v gosto poseljenih } \\
\text { območjih }\end{array}$ & $\begin{array}{l}\text { Delež prebivalcev v naseljih z več kot } \\
386 \text { preb./km }{ }^{2}\end{array}$ & 2011 \\
\hline Urbana gostota & Delež urbanih območij na hektar regije & 2011 \\
\hline
\end{tabular}


Podeželje. Kazalci opisujejo predvsem kmetijsko funkcijo podeželja. Podatki so povzeti iz popisa kmetijskih gospodarstev iz leta 2010 (Popis kmetijskih gospodarstev 2010, 2011).

Preglednica 5: Razvojni položaj Gorenjske statistične regije - kazalci razvoja podeželja Table 5: Developmental condition of Gorenjska statistical region-indicators of countryside

\begin{tabular}{|l|l|l|}
\hline Kazalec & Izračun vrednosti kazalca & Leto podatkov \\
\hline Gorska in hribovita območja & $\begin{array}{l}\text { Delež površine regije z nadmorsko } \\
\text { višino nad } 600 \mathrm{~m}\end{array}$ & 2010 \\
\hline $\begin{array}{l}\text { Aktivno kmečko prebivalstvo - } \\
\text { starostna struktura }\end{array}$ & $\begin{array}{l}\text { Delež gospodarjev-upraviteljev } \\
\text { kmetijskih gospodarstev, mlajših od } \\
45 \text { let }\end{array}$ & 2010 \\
\hline $\begin{array}{l}\text { Aktivno kmečkoprebivalstvo - } \\
\text { kvalifikacijska struktura }\end{array}$ & $\begin{array}{l}\text { Delež gospodarjev-upraviteljev } \\
\text { kmetijskih gospodarstev s srednjo ali } \\
\text { višjo stopnjo izobrazbe }\end{array}$ & 2010 \\
\hline Čisti kmetje & $\begin{array}{l}\text { Delež samozaposlenih oseb - kmetov v } \\
\text { aktivnem prebivalstvu }\end{array}$ & 2010 \\
\hline Velikost kmetij & $\begin{array}{l}\text { Delež kmetijskih gospodarstev, večjih } \\
\text { od } 10 \text { ha }\end{array}$ & 2010 \\
\hline Ekološke kmetije & $\begin{array}{l}\text { Delež kmetijskih gospodarstev z } \\
\text { ekološkim kmetovanjem }\end{array}$ & 2010 \\
\hline Dopolnilne dejavnosti na kmetijah & $\begin{array}{l}\text { Delež kmetijskih gospodarstev z } \\
\text { dopolnilno dejavnostjo }\end{array}$ & 2010 \\
\hline
\end{tabular}

Kakovost življenja. Podatki izvirajo iz različnih podatkovnih baz Statističnega urada Republike Slovenije.

Preglednica 6: Razvojni položaj Gorenjske statistične regije - kazalci kakovosti življenja Table 6: Developmental condition of Gorenjska statistical region - indicators of quality of living

\begin{tabular}{|l|l|l|}
\hline Kazalec & Izračun vrednosti kazalca & Leto podatkov \\
\hline Nova stanovanja & $\begin{array}{l}\text { Število novih stanovanj na } 1000 \\
\text { prebivalcev v zadnjih petih in zadnjih } \\
\text { devetih letih - povprečni rang }\end{array}$ & $\begin{array}{l}2002-2011,2007- \\
2011\end{array}$ \\
\hline Življenjski standard - število stanovanj & Število stanovanj na 1000 prebivalcev & 2011 \\
\hline Življenjski standard $-\mathrm{m}^{2} /$ preb. & $\begin{array}{l}\text { Povprečna površina stanovanja na } \\
\text { prebivalca }\end{array}$ & 2011 \\
\hline Kazalec zdravja & Delež umrlih, mlajših od 65 let & 2011 \\
\hline
\end{tabular}

Infrastruktura. Za obravnavano skupino kazalcev smo dobili zelo majhno število podatkov. Od 26 kazalcev smo uspeli zbrati podatke le za šest, kar predstavlja zgolj 23 \% 
vseh kazalcev. Za državno raven je mogoče dobili podatke za 15 kazalcev, medtem ko je podatkov na nižjih prostorskih ravneh zelo malo.

Preglednica 7: Razvojni položaj Gorenjske statistične regije - kazalci infrastrukture Table 7: Developmental condition of Gorenjska statistical region-indicators of infrastructure

\begin{tabular}{|l|l|l|}
\hline Kazalec & Izračun vrednosti kazalca & Leto podatkov \\
\hline Stopnja motorizacije & $\begin{array}{l}\text { Število registiranih vozil na } 1000 \\
\text { prebivalcev }\end{array}$ & 2011 \\
\hline Gostota cest - državne ceste & $\begin{array}{l}\text { Gostota avtocest, hitrih cest ter glavnih } \\
\text { cest I. in II. reda }\left(\mathrm{km} / \mathrm{km}^{2}\right)\end{array}$ & 2011 \\
\hline Gostota cest - regionalne ceste & $\begin{array}{l}\text { Gostota regionalnih cest I., II., III., IV. } \\
\text { reda in regionalnih turističnih cest }(\mathrm{km} / \\
\left.\text { km }{ }^{2}\right)\end{array}$ & 2011 \\
\hline Gostota cest - občinske ceste & Gostota občinskih cest $\left(\mathrm{km} / \mathrm{km}^{2}\right)$ & 2011 \\
\hline Oskrba s pitno vodo & $\begin{array}{l}\text { Količina načrpane vode iz vseh vodnih } \\
\text { virov }\left(\mathrm{m}^{3}\right) \text { na prebivalca }\end{array}$ & 2011 \\
\hline Poraba vode & $\begin{array}{l}\text { Voda, dobavljena gospodinjstvom, na } \\
\text { prebivalca }\left(\mathrm{m}^{3}\right)\end{array}$ & 2011 \\
\hline
\end{tabular}

Raba zemljišč. Vrednosti kazalcev smo izračunali iz podatkov Ministrstva za kmetijstvo, gozdarstvo in prehrano, oziroma iz njihove aplikacije GERK (2011).

Preglednica 8: Razvojni položaj Gorenjske statistične regije - kazalci rabe zemljišč Table 8: Developmental condition of Gorenjska statistical region-indicators of land use

\begin{tabular}{|l|l|l|}
\hline Kazalec & Izračun vrednosti kazalca & Leto podatkov \\
\hline Kmetijska zemljišča & $\begin{array}{l}\text { Delež kmetijskih zemljišč v površini } \\
\text { regije }\end{array}$ & 2011 \\
\hline Njive & Delež njiv v površini regije & 2011 \\
\hline Travniki & Delež travnikov v površini regije & 2011 \\
\hline Gozd & Delež gozda v površini regije & 2011 \\
\hline Vodne površine & Delež vodnih površin v površini regije & 2011 \\
\hline Pozidana zemljišča & $\begin{array}{l}\text { Delež pozidanih površin v površini } \\
\text { regije }\end{array}$ & 2011 \\
\hline
\end{tabular}

Zavarovana območja. Vse potrebne sloje vektorskih podatkov za izračun kazalcev smo pridobili od Agencije Republike Slovenije za okolje (Geoportal ARSO, 2013). Sloji so bili za celotno državo, do podatkov po statističnih regijah smo prišli z uporabo GIS orodij. 
Preglednica 9: Razvojni položaj Gorenjske statistične regije - kazalci zavarovanih območij Table 9: Developmental condition of Gorenjska statistical region - indicators of protected areas

\begin{tabular}{|l|l|l|}
\hline Kazalec & Izračun vrednosti kazalca & Leto podatkov \\
\hline Zavarovana območja & $\begin{array}{l}\text { Delež površine statistične regije, ki jo } \\
\text { zajemajo vsa zavarovana območja }\end{array}$ & 2013 \\
\hline Območja Natura 2000 & $\begin{array}{l}\text { Delež površine statistične regije, ki jo } \\
\text { zajemajo območja Natura } 2000\end{array}$ & 2013 \\
\hline Vodovarstvena območja & $\begin{array}{l}\text { Delež površine statistične regije, ki jo } \\
\text { zajemajo vodovarstvena območja }\end{array}$ & 2013 \\
\hline
\end{tabular}

Degradirana območja. Podatke smo povzeli po kazalcih okolja Agencije Republike Slovenije za okolje (Kazalci okolja ..., 2011).

Preglednica 10: Razvojni položaj Gorenjske statistične regije - kazalci degradiranih območij Table 10: Developmental condition of Gorenjska statistical region - indicators of degraded areas

\begin{tabular}{|l|l|l|}
\hline Kazalec & Izračun vrednosti kazalca & Leto podatkov \\
\hline Degradirana območja & $\begin{array}{l}\text { Število evidentiranih degradiranih } \\
\text { območij na } 100.000 \text { prebivalcev }\end{array}$ & 2011 \\
\hline Onesnaženost prsti & Verjetnost tveganja onesnaženja & 2011 \\
\hline Onesnaženost zraka & $\begin{array}{l}\text { Koliko preseženih vrednosti } \\
\text { posameznih snovi je prisotnih v zraku? }\end{array}$ & 2011 \\
\hline Onesnaženost vode & Kemijsko stanje vode & 2011 \\
\hline Onesnaženost podzemne vode & Kemijsko stanje vode & 2011 \\
\hline
\end{tabular}

Ogrožena območja. Površino ogroženih območij po statističnih regijah smo, podobno kot zavarovanih območij, izračunali iz prostorskih podatkov Ministrstva za okolje in prostor (Podatkovne baze..., 2011) z uporabo GIS orodij.

Preglednica 11: Razvojni položaj Gorenjske statistične regije - kazalci ogroženih območij Table 11: Developmental condition of Gorenjska statistical region-indicators of endangered areas

\begin{tabular}{|l|l|l|}
\hline Kazalec & Izračun vrednosti kazalca & Leto podatkov \\
\hline Poplavna območja & $\begin{array}{l}\text { Delež poplavnih območij v površini } \\
\text { regije }\end{array}$ & 2005 \\
\hline Erozijska območja & $\begin{array}{l}\text { Delež erozijskih območij v površini } \\
\text { regije }\end{array}$ & 2005 \\
\hline Območja snežnih plazov & $\begin{array}{l}\text { Delež območij snežnih plazov v površini } \\
\text { regije }\end{array}$ & 2005 \\
\hline $\begin{array}{l}\text { Ocenjena finančna škoda zaradi } \\
\text { naravnih nesreč }\end{array}$ & $\begin{array}{l}\text { Finančna škoda zaradi naravnih nesreč } \\
\text { (EUR/preb.) }\end{array}$ & 2008 \\
\hline
\end{tabular}




\section{RAZVOJNI POLOŽAJ GORENJSKE STATISTIČNE REGIJE: PRIMERJALNA ANALIZA}

\section{I. Demografska struktura}

Gorenjska je s 95,5 preb./ $\mathrm{km}^{2}$ srednje gosto naseljena slovenska regija. V primerjavi z najgosteje naseljeno Osrednjeslovensko (210 preb./ $\mathrm{km}^{2}$ ) ima pol manjšo gostoto poselitve, a je skoraj trikrat gosteje naseljena kot regija z najnižjo gostoto poselitve (Notranjsko-kraška: 36 preb. $/ \mathrm{km}^{2}$ ).

Slika 1: Razvojni položaj Gorenjske z vidika demografske strukture

Figure 1: Ranking of Gorenjska statistical region according to demographic structure

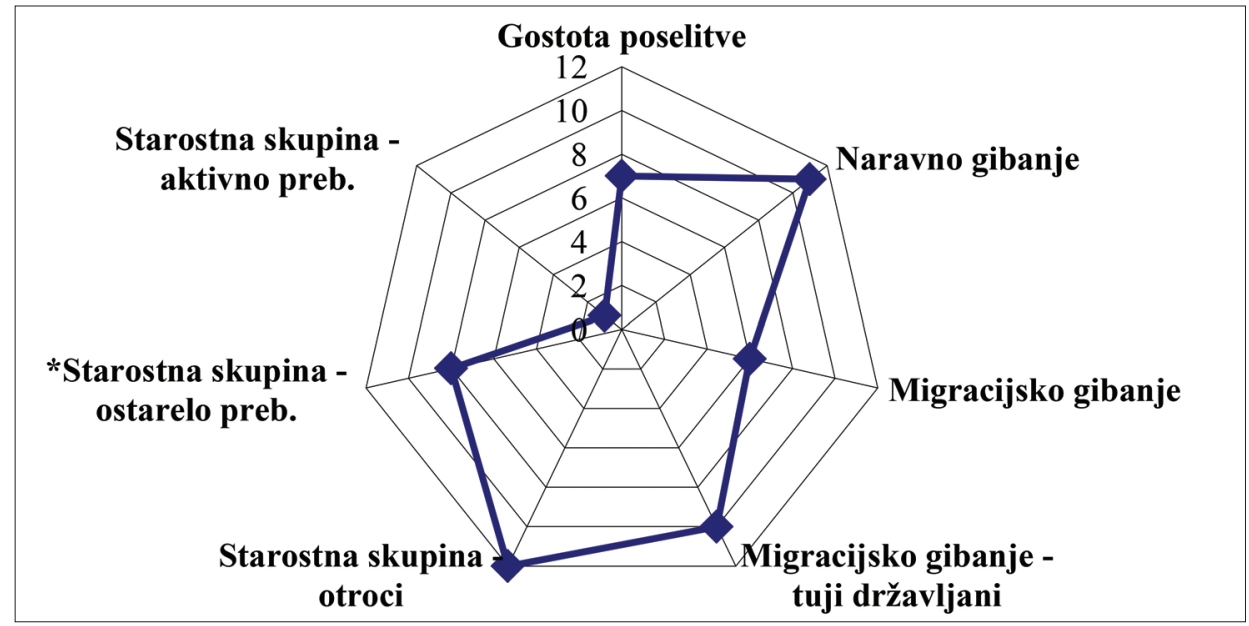

Vir/Source: SURS, 2013

Demografska struktura Gorenjske je razmeroma zelo ugodna. Delež prebivalcev v starosti do 15 let je najvišji v Sloveniji (15,4\%). K temu pomembno prispeva visok naravni prirastek, saj je regija s 3,2 \%o na drugem mestu v Sloveniji, višjega ima samo Osrednjeslovenska regija (4,75\%). Posledično je delež starejšega prebivalstva v primerjavi z drugimi regijami relativno nizek (16,9 \%), a vseeno višji od štirih regij (Jugovzhodna Slovenija, Osrednjeslovenska, Savinjska in Koroška regija). Gorenjska ima najnižji delež prebivalcev v starostni skupini 15-64 let.

Gorenjska izgublja na skupnem številu prebivalcev zaradi odseljevanja. V letu 2011 je bila emigracijsko območje, saj je regijo zapustilo 16 oseb več, kot se jih je priselilo (selitveni prirast -0,08\%o). Kljub temu je med bolj priljubljenimi destinacijami za priseljevanje iz tujine; bolj privlačni od nje sta bili le Obalno-kraška in Goriška regija.

Kazalci demografske strukture kažejo, da ima regija razmeroma ugodno strukturo, ki se odraža na področju naravnega gibanja prebivalstva, in s tem tudi največjim deležem mladega prebivalstva. Zanimivo je, da se regija pri deležu prebivalstva v starostni skupini 
med 15 in 64 leti starosti uvršča v spodnji del ranga slovenskih regij. Iz regije se sicer odseli več prebivalcev, kot se jih priseli, zato je migracijsko gibanje negativno, priseljevanje tujih državljanov v regijo pa je med najmočnejšimi.

\subsection{Socio-ekonomska struktura}

Osrednjeslovenska regija ima z več kot 24.000 EUR/preb. (2010) daleč najvišji BDP/ preb. Gorenjska se z mnogo nižjim BDP/preb. (14.408 EUR/preb.) uvršča v drugo polovico regij v Sloveniji (rang 5). Nekoliko ugodnejši položaj ima Gorenjska v deležu BDP, ki ga ustvarijo storitvene dejavnosti (rang 9). Z deležem BDP za raziskave in razvoj se Gorenjska uvršča med regije z najvišjimi rangi, še višji pa je položaj Gorenjske pri zaposlenih na področju raziskav in razvoja.

Slika 2: Razvojni položaj Gorenjske z vidika socio-ekonomske strukture

Figure 2: Ranking of Gorenjska statistical region according to socio-economic structure

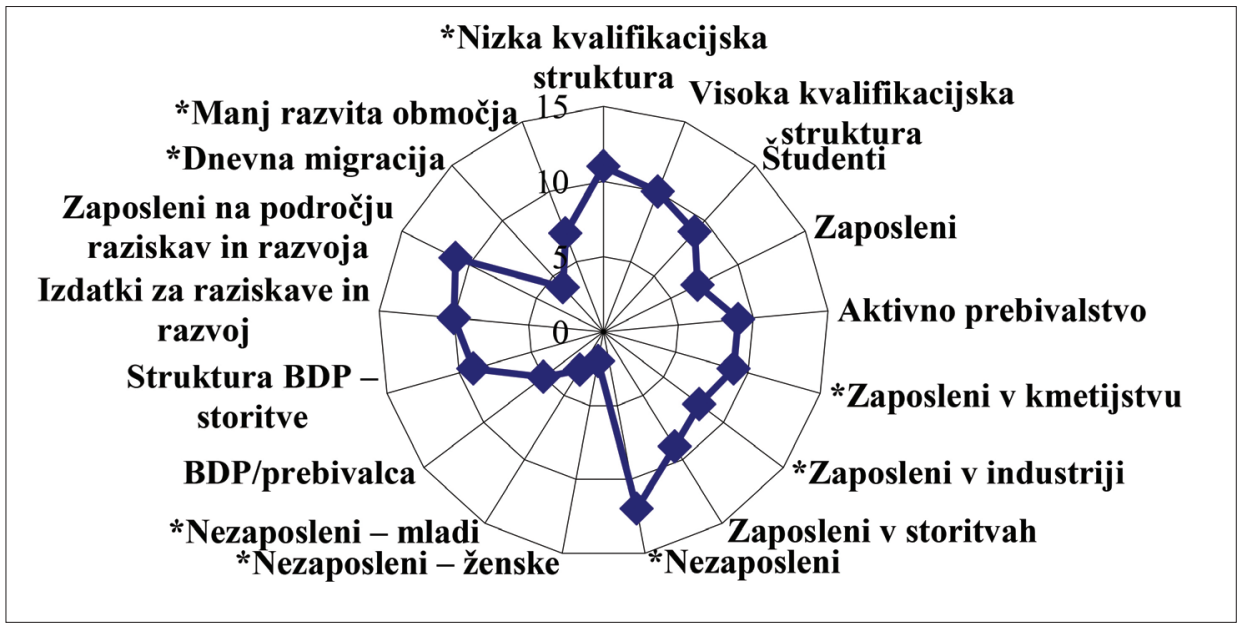

Viri/Sources: SURS, 2013; Uredba o določitvi ..., 2011; Zakon o spodbujanju skladnega regionalnega razvoja, 2011

Podobno ugodne vrednosti ima Gorenjska tudi na področju kvalifikacijske strukture ter števila študentov. S temi kazalci se Gorenjska uvršča v zgornjo četrtino regij z najugodnejšimi vrednostmi. Podobno je tudi v strukturi zaposlenih po sektorjih, le da se v tem primeru regija nahaja na robu zgornje tretjine, pri čemer je delež zaposlenih v storitvenih dejavnostih v regiji v primerjavi z deležem zaposlenih v primarnem in sekundarnem sektorju relativno visok.

Gorenjska ima indeks delovne migracije nizek, kar jo uvršča med najbolj bivalne regije v Sloveniji (rang 4); bolj bivalne so le še Zasavska, Spodnjeposavska in Notranjsko-kraška regija. 
Stopnja registirane brezposelnosti je najnižja v Sloveniji. Regija se je s tem kazalcem uvrstila v najvišji rang, saj je v regiji brezposelnih le $10 \%$ aktivnih prebivalcev. Bolj problematična je brezposelnost med mladimi, kjer se je Gorenjska znašla na repu (rang 3).

Gorenjska ima relativno veliko obmejnih problemskih območij (rang 7). Ta obsegajo skoraj polovico regije, na njih pa živi slaba petina prebivalcev.

Socio-ekonomska struktura regije je opredeljena na podlagi največjega števila kazalcev (17). S tega vidika regija pozitivno izstopa $\mathrm{z}$ nadpovprečnim številom aktivnega prebivalstva, zaposlenih $\mathrm{v}$ kmetijstvu, industriji in storitvah, z ugodno kvalifikacijsko strukturo zaposlenih. Posebnega pomena za položaj regije je visoka zaposlenost na področju raziskav in razvoja in s tem povezanimi izdatki za raziskave in razvoj. Brezposelnost je med najnižjimi v državi, vendar je med brezposelnimi izredno veliko mladega in ženskega prebivalstva. Kljub temu se regija po gospodarski moči uvršča v slovensko povprečje. Leta 2013 je Gorenjska spadala med šest regij, ki so imele neto čisto izgubo v gospodarstvu in se je po tem kazalcu uvrstila na osmo mesto.

\subsection{Poselitvena struktura}

Skupina kazalcev o poselitveni strukturi kaže razmerja med celotno površino oziroma številom prebivalcev in urbanimi območji. Gorenjska se po deležu urbanih površin in urbani gostoti uvršča med bolj urbane regije v Sloveniji (zgornja tretjina). V urbanih območjih prebiva malo več kot polovica prebivalcev Gorenjske (53,8 \%; rang 9), kar je malo nad državnim povprečjem (49,8 \%). Višji delež urbanega prebivalstva imajo Obalno-kraška, Zasavska in Osrednjeslovenska regija. Podobna razmerja so tudi pri deležu prebivalcev, ki prebivajo $\mathrm{v}$ naseljih $\mathrm{z}$ visoko gostoto prebivalcev. V suburbanih območij prebiva dobra četrtina prebivalcev (27,4 \%), kar uvršča Gorenjsko v rang 8. Po urbani gostoti, ki kaže delež urbanih območij v regiji, je Gorenjska nadpovprečno gosto poseljena

Slika 3: Razvojni položaj Gorenjske z vidika poselitvene strukture

Figure 3: Ranking of Gorenjska statistical region according to settlement structure

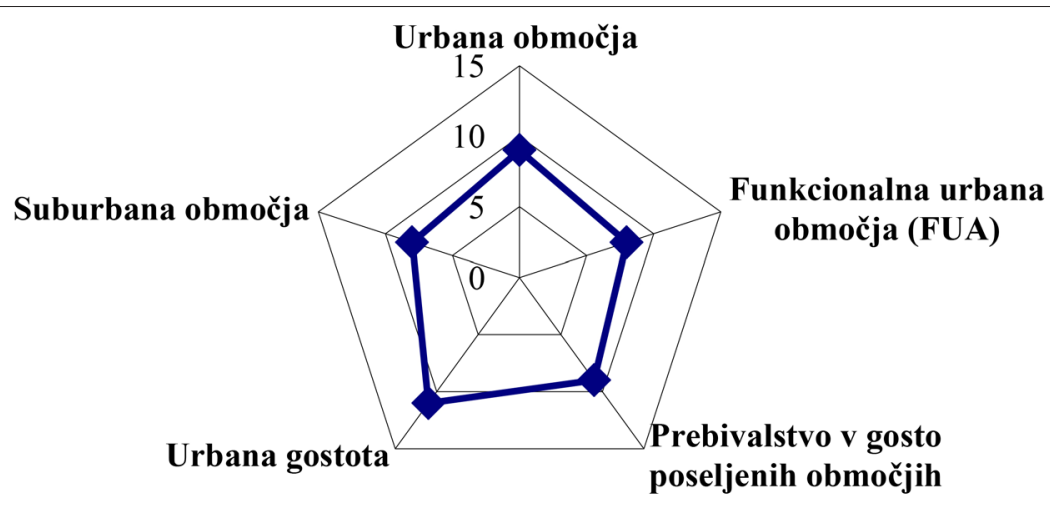

Viri/Sources: Kušar, Pichler-Milanović, 2010; Pregled mestnih naselij ..., 2009; SURS, 2013 
znotraj urbanih območij, saj se je uvrstila na rang 11 in zaostaja le za Osrednjeslovensko regijo. Relativno 'urbanost' regije dokazujeta tako povprečni rang (9) kot tudi končni rang, pri katerem se Gorenjska z rangom 10 uvršča med bolj urbane regije v Sloveniji. Bolj (sub)urban značaj imata le še Obalno-kraška in Osrednjeslovenska regija.

\subsection{Podeželje}

Gorenjska ima zaradi reliefnih značilnosti najvišji delež gorskih in hribovitih območij med vsemi regijami. Območja z nadmorskimi višinami nad 600 m zajemajo kar 64,4 \% celotne površine regije, kar je skoraj dvakrat več od slovenskega povprečja (32,6 \%). Starostna struktura gospodarjev na kmetijah je ugodna, kar uvršča regijo na rang 11 , v enak rang se uvršča tudi po njihovi splošni izobrazbi. Delež gospodarjev na kmetijah, ki se ukvarjajo izključno s kmetovanjem, dosega 33 \%, s čimer se Gorenjska uvršča v sredino regij (rang 6), so pa kmetije nadpovprečno velike (rang 11). Kmetje so v povprečju zelo podjetni, saj ima Gorenjska nadpovprečno število kmetij z dopolnilnimi dejavnostmi (rang 11), nekoliko manj pomembno je ekološko kmetovanje (rang 9).

Slika 4: Razvojni položaj Gorenjske z vidika razvoja podeželja

Figure 4: Ranking of Gorenjska statistical region according to countryside

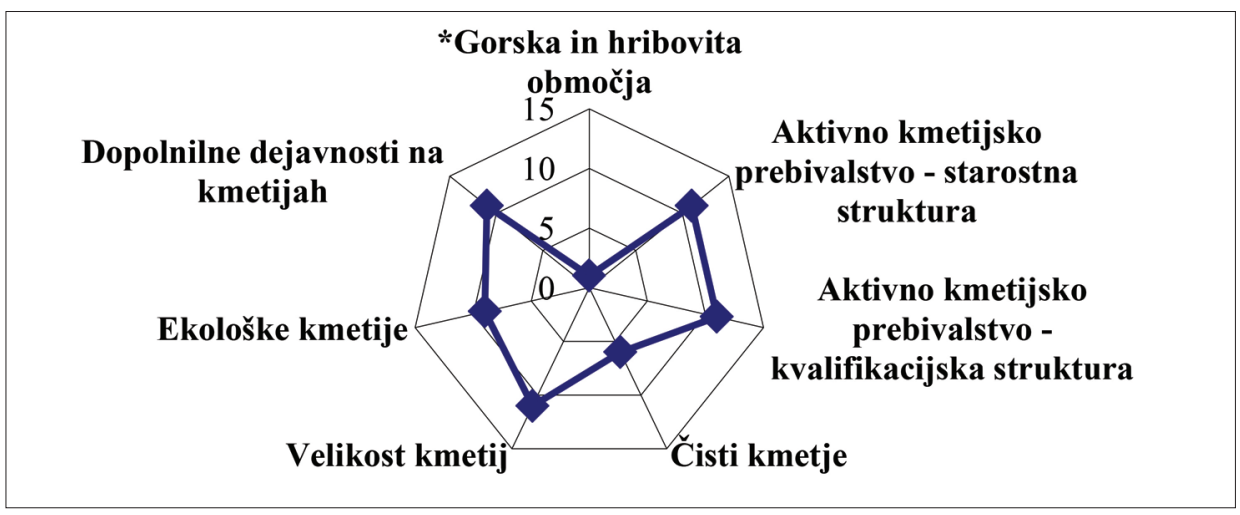

Vir/Source: Popis kmetijskih gospodarstev 2010, 2011

Na gorenjskem podeželju, ki obsega velik delež gorskih in hribovitih območij, je razmeroma malo kmetij in med njimi tudi malo čistih kmetij, ki pa so v povprečju največje med slovenskimi regijami. Stabilnost primarne dejavnosti (odlikuje jo tudi ekološko kmetovanje) se kaže tudi v nadpovprečno uspešnem uvajanju dopolnilnih dejavnosti na kmetijah. Ugotovitve o pretežno ugodni socio-posestni strukturi in kmetijski pridelavi, ki ugodno vplivata na strukturo podeželja, podpirata tudi povprečni rang $(8,57)$ in končni rang za to skupino kazalcev (rang 11). 


\subsection{Kakovost življenja}

Kakovost življenja je kazalec, ki je navezan na količinske podatke o stanovanjskem fondu (število novih stanovanj, število stanovanj na 1000 prebivalcev) in kazalec zdravja. Po številu novo zgrajenih stanovanj na 1000 prebivalcev med letoma 2002 in 2011 se Gorenjska z rangom 9 uvršča med bolj dinamične regije v Sloveniji. Večja investicijska dejavnost na področju stanovanjske gradnje je bila v preučevanem obdobju le v Obalno-kraški, Podravski in Osrednjeslovenski regiji. Kljub temu je življenjski standard, merjen s številom stanovanj na 1000 prebivalcev in povprečno velikostjo stanovanja na prebivalca, relativno nizek, saj se Gorenjska uvršča med statistične regije z nižjimi rangi (2 oziroma 6). Relativno kakovost življenja v regiji izboljšuje kazalec zdravja, s katerim se Gorenjska uvršča na rang 10, oziroma med regije z najnižjim deležem umrlih, mlajših od 65 let. Povprečni rang na področju kakovosti življenja znaša 6,75, s čimer se Gorenjska statistična regija uvršča na končni rang 7 . S tega vidika je Gorenjska v primerjavi z ostalimi regijami povprečno razvita. Stanovanjski fond je torej slabši, kot bi pričakovali glede na dobro uvrstitev pri drugih kazalcih.

Slika 5: Razvojni položaj Gorenjske z vidika kakovosti življenja

Figure 5: Ranking of Gorenjska statistical region according to quality of living

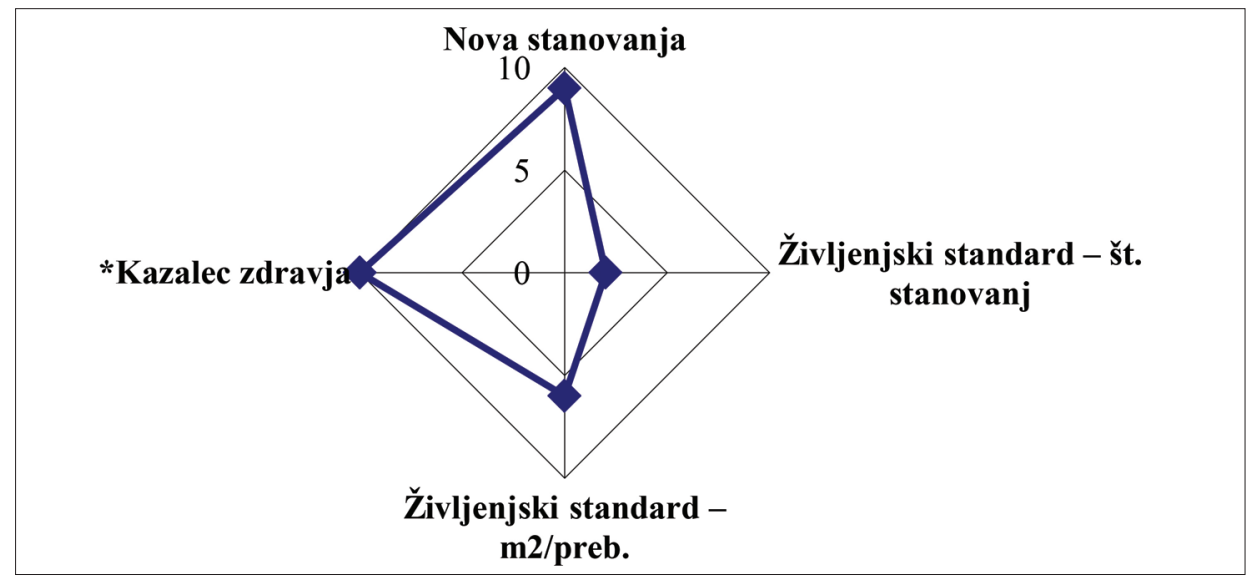

Vira/Sources: Slovenske regije v številkah, 2013; SURS, 2013

\subsection{Infrastruktura}

$\mathrm{Na}$ Gorenjskem je registriranih 653,37 vozil na 1000 prebivalcev, kar jo z rangom 3 uvršča med regije z najmanjšo stopnjo motorizacije. Nižja je bila konec leta 2011 zabeležena le še v Koroški in Zasavski regiji. Gorenjska je imela približno 100 vozil na 1000 prebivalcev manj kot Notranjsko-kraška in Goriška regija, ki sta se pri rangiranju uvrstili najvišje. 
Slika 6: Razvojni položaj Gorenjske z vidika infrastrukture

Figure 6: Ranking of Gorenjska statistical region according to infrastructure

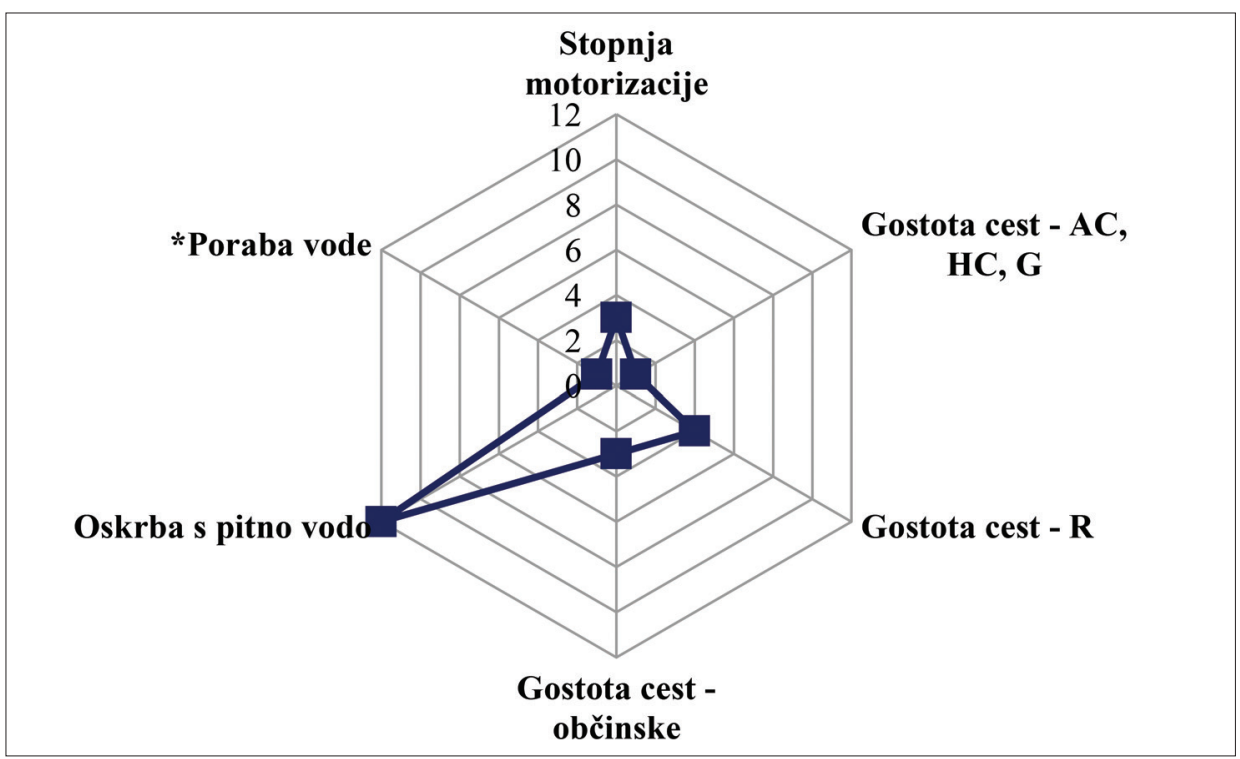

Vir/Source: Cestna vozila ..., 2013

Pri gostoti cest Gorenjska prav tako odstopa v smeri nižjih vrednosti kazalca. Pri gostoti avtocest, hitrih cest ter glavnih cest I. in II. reda je z $0,0462 \mathrm{~km} / \mathrm{km}^{2}$ na zadnjem mestu (rang 1). Nekoliko bolje je preučevana regija uvrščena pri gostoti regionalnih cest (rang 4), še malo bolje, a še vedno v drugi polovici regij, pa pri gostoti občinskih cest (rang 5). Za Gorenjsko je torej značilna nizka gostota prometne mreže, kar je posledica reliefnih razmer ter izrazite zgoščenosti poselitve v osrednjem, kotlinsko-ravninskem delu regije.

Regija se veliko bolje uvršča pri kazalcih načrpane in porabljene vode. Na Gorenjskem načrpajo največ vode na prebivalca $\left(97,4 \mathrm{~m}^{3} /\right.$ preb.), oziroma dvakrat več kot je načrpajo v zadnje uvrščeni Koroški regiji (47,15 m³/preb.), s čimer se Gorenjska uvršča na prvo mesto (rang 12). Gorenjska prednjači tudi po porabi vode, kjer je bila zato uvrščena v najnižji rang.

Po gostoti cest različnih kategorij se Gorenjska uvršča v spodnji del rangov, prav tako pri stopnji motorizacije. Tretji in četrti kazalec (vodovodni sistemi in poraba vode) pa kažeta, da sta vodovodno omrežje in s tem oskrba z vodo razmeroma dobro urejena, je pa poraba pitne vode v regiji med največjimi v državi. Povprečni rang pri analiziranih kazalcih s področja infrastrukture znaša 4,33, kar Gorenjsko uvršča na zadnji rang (1). Z vidika infrastrukturne opremljenosti ima torej Gorenjska statistična regija slab položaj. 


\subsection{Raba zemljišč}

Ob veliki gozdnatosti (rang 10; gozdovi prekrivajo skoraj 70 \% površine) ima Gorenjska le $362,5 \mathrm{~km}^{2}$ kmetijskih zemljišč oziroma 17 \% površine, kar jo uvršča na zadnje mesto med vsemi regijami. V primerjavi s Pomursko regijo, ki ima najvišji delež kmetijskih zemljišč (59,7 \%), je delež teh zemljišč na Gorenjskem več kot polovico manjši. Med kmetijskimi zemljišči je v Gorenjski regiji največ travnikov in pašnikov (njive 107,4 $\mathrm{km}^{2}$ oziroma $5 \%$ površine regije; travniki in pašniki $241,9 \mathrm{~km}^{2}$ oziroma $11,3 \%$ površine statistične regije). Kljub temu se je v primerjavi z drugimi regijami Gorenjska uvrstila ugodneje pri deležu njiv (rang 6) kot pri travnikih (rang 2).

Slika 7: Razvojni položaj Gorenjske z vidika rabe zemljišč

Figure 7: Ranking of Gorenjska statistical region according to land use

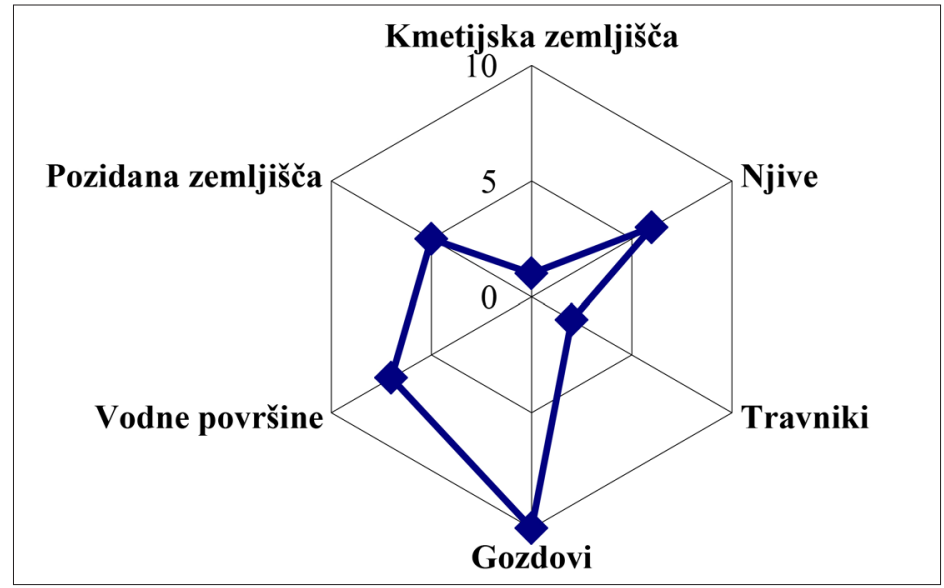

Vir/Source: GERK, 2011

Po deležu vodnih površin se Gorenjska uvršča v sredino regij (rang 7), medtem ko podatki o pozidanih površinah $\left(47,1 \mathrm{~km}^{2} ; 2,2\right.$ \% površine; rang 5) kažejo, da se Gorenjska uvršča med regije $\mathrm{z}$ manjšim deležem pozidanih zemljišč.

Gorenjska se v tej skupini kazalcev s povprečnim rangom 5,17 uvršča v zadnjo četrtino regij v Sloveniji (rang 3). Z vidika rabe zemljišč ima regija razmeroma majhen delež kmetijskih zemljišč, pri katerih v primerjavi z drugimi regijami po pomenu izstopajo njive in v manjši meri travniki. Razmeroma precejšen je delež vodnih površin. Po deležu gozdnih površin je regija med najbolj gozdnatimi v Sloveniji, kar pomembno izboljšuje njen razvojni položaj na področju primarnega sektorja.

\subsection{Zavarovana območja}

Različne vrste zavarovanih območij (narodni park, krajinski parki, zavarovani gozdovi, naravni spomeniki, ipd.) obsegajo 37,3 \% Gorenjske regije. S tem deležem zaostaja 
le za Pomursko (43,3 \%) in Notranjsko-kraško regijo (47,1 \%). Delež območij Natura 2000 je celo še večji, saj zajemajo kar 44,3 \% površine Gorenjske, kljub temu pa se regija uvršča šele v rang 8: višji delež območij Natura 2000 imajo namreč Notranjsko-kraška regija, Jugovzhodna Slovenija, Obalno-kraška in Goriška regija, vendar le za nekaj odstotnih točk, z izjemo Notranjsko-kraške regije, kjer Natura 2000 obsega več kot polovico regije $(53,7 \%)$.

Slika 8: Razvojni položaj Gorenjske z vidika zavarovanih območij

Figure 8: Ranking of Gorenjska statistical region according to protected areas

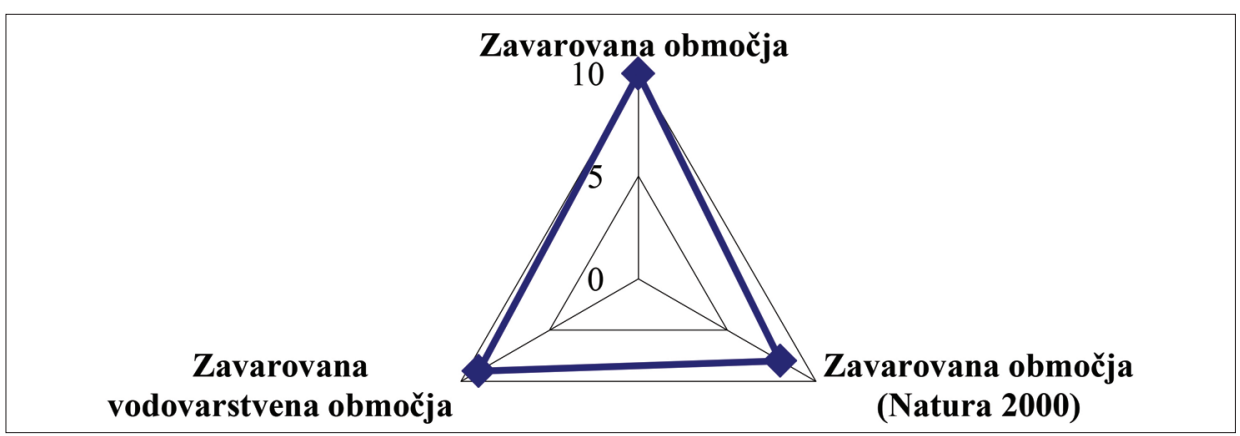

Vir/Source: Geoportal ARSO, 2013

Podobno strukturo ima Gorenjska regija tudi na področju vodovarstvenih območij, kjer se uvršča v rang 9. Vodovarstvena območja so pomembnejša varstvena kategorija le v Obalno-kraški, Podravski in Osrednjeslovenski regiji.

Povprečni rang pri analiziranih kazalcih znaša 9, s katerim se Gorenjska uvršča na končni rang 10 .

\subsection{Degradirana območja}

Gorenjska se z izjemo števila degradiranih območij na 100.000 prebivalcev, kjer se je z 10,81 evidentiranih degradiranih območij uvrstila v povprečje slovenskih regij (rang 7), uvršča med manj degradirane regije. Najbolje je bila uvrščena pri analizi kakovosti voda, kjer je pri površinskih in podzemnih vodah zasedla najvišji rang, le nekoliko slabša je bila pri kakovosti prsti in zraka (obakrat rang 10). To dokazuje tudi povprečni rang 10,2, ki Gorenjsko uvršča na 11. rang. Bolje je bila ocenjena le Jugovzhodna Slovenija, ker ima nekoliko manj degradiranih območij na 100.000 prebivalcev, medtem ko je pri ostalih kazalcih dosegala enake range kot Gorenjska. 
Slika 9: Razvojni položaj Gorenjske z vidika degradiranih območij

Figure 9: Ranking of Gorenjska statistical region according to degraded areas

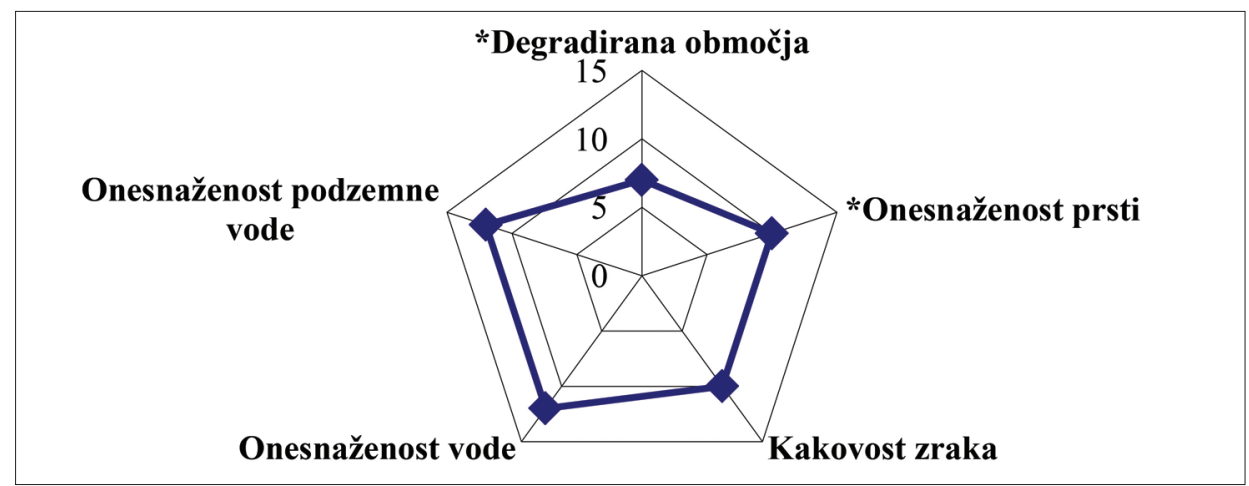

Vir/Source: Kazalci okolja v Sloveniji 2011, 2013

\subsection{Ogrožena območja}

Glede na reliefne značilnosti Gorenjske je po pričakovanju delež poplavnih območij relativno nizek $(0,88$ \% površine regije), s čimer se uvršča v rang 10 . Nižji delež poplavnih območij imata le Zasavska in Koroška regija. V nasprotju s tem podatkom se Gorenjska v veliko večji meri sooča s problematiko erozijskih in plazovitih območij (rang 4) ter območij s snežnimi plazovi (rang 2). Kljub temu je škoda zaradi naravnih nesreč ocenjena kot nizka (rang 11).

Slika 10: Razvojni položaj Gorenjske z vidika ogroženih območij

Figure 10: Ranking of Gorenjska statistical region according to endangered areas

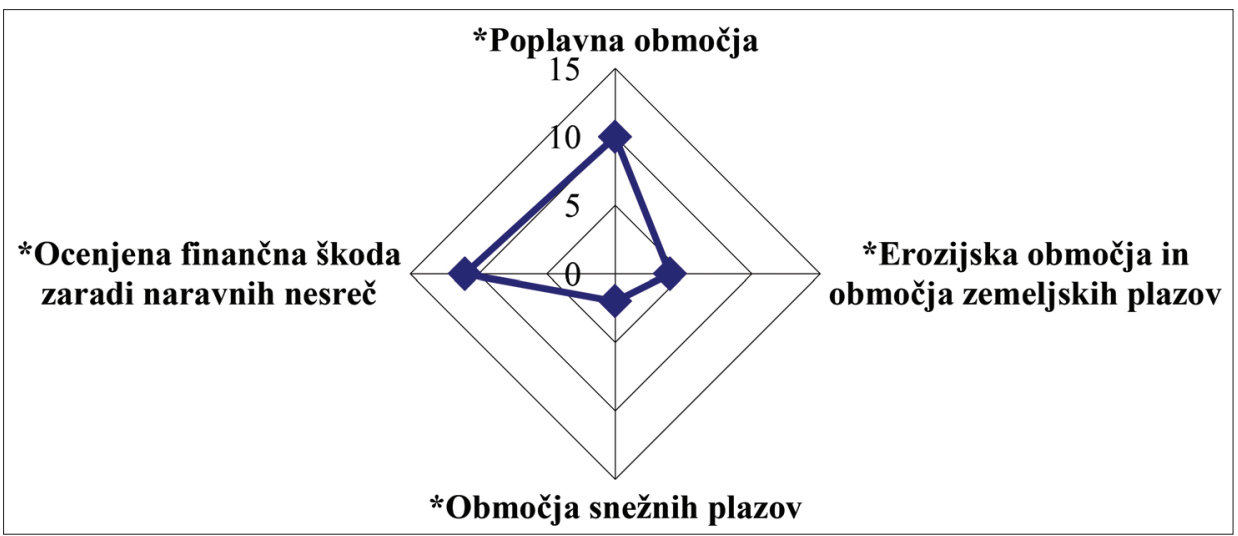

Vira/Sources: Podatkovne baze o poplavnih območjih..., 2011; SURS, 2013 


\section{SKLEP}

Poskus ocene relativnega razvojnega položaja Gorenjske statistične regije na podlagi skupin kazalcev, ki merijo razvoj na področju demografske in socialno-ekonomske strukture, mreže naselij, podeželja, kakovosti bivanja, infrastrukture, rabe zemljišč, zavarovanih območij, degradiranih in ogroženih območij ter standardizacije in rangiranja, nam kaže naslednje razvojne prednosti preučevane regije:

Gorenjska se uvršča v zgornjo tretjino statističnih regij z najugodnejšo demografsko strukturo. Regija ima torej razmeroma kakovosten človeški kapital in dobre osnove za prihodnji razvoj, z visokim naravnim prirastkom pa ta razvojni potencial tudi ohranja.

Regija je doživela intenzivno deindustrializacijo. Kljub relativno šibki gospodarski moči je lahko nadpovprečno visok delež BDP, namenjen raziskavam in razvoju, trdna razvojna podlaga in predstavlja primeren potencial za prihodnji razvoj gospodarstva, $\mathrm{s}$ tem pa tudi regionalni razvoj Gorenjske statistične regije.

Naravne značilnosti Gorenjske regije, relativno zgodnja industrializacija, značaj poselitve in dobra prometna prehodnost v Ljubljanski kotlini so prispevali k oblikovanju gručastih naselij in mreže urbanih naselij. V novejšem času prihaja zaradi procesa suburbanizacije do večje prebivalstvene gostote tudi na suburbanih območjih.V primerjavi z drugimi statističnimi regijami je Gorenjska zelo urbanizirana, kar lahko v večji meri pozitivno vpliva na razvoj širših in lokalnih (podeželje) razvojnih pobud.

Zavarovana območja kažejo visok pomen naravnih vrednot in naravno ohranjenih območij, tako po deležu vseh zavarovanih območij kot po deležu zavarovanih vodovarstvenih območij in območij Natura 2000. Ta območja lahko predstavljajo pomemben razvojni dejavnik za možne razvojne koncepte Gorenjske statistične regije.

Glede na fizičnogeografske značilnosti lahko sklepamo, da je regija med bolj ogroženimi območji, vsaj z vidika erozijskih območij in območij zemeljskih ter snežnih plazov.

Relevantnost uporabljenega teoretično-metodološkega pristopa in rezultatov analize potrjujejo ugotovitve, navedene v znanstveni monografiji, ki je izšla ob 21. zborovanju slovenskih geografov na Gorenjskem oktobra 2013. Avtorji prispevkov v monografiji se namreč dotikajo nekaterih elementov, ki so vključeni tudi v predstavljeno analizo. Med temeljnimi razvojnimi značilnostmi izpostavljajo intenzivno deindustrializacijo ob hkratni vedno večji vlogi storitvenih dejavnosti ter rasti števila ustvarjalnih poklicev (Kozina, 2013). Zaradi izgube nekdanje gospodarske vloge je Gorenjska v večji meri navezana na delovna mesta $\mathrm{v}$ sosednjih regijah, kar se kaže v intenzivni dnevni mobilnosti delovne sile. Tok je usmerjen predvsem v Osrednjeslovensko statistično regijo oziroma Ljubljano (Rus, Razpotnik Visković, Nared, 2013). V gospodarstvu regije izstopa tudi nizek delež ljudi, ki delajo v kmetijstvu (Cunder, Lampič, 2013). Gorenjska izstopa po visoki stopnji urbanizacije in obsežnih suburbanih območjih ter urbaniziranem podeželju (Gabrovec, Bole, 2013; Kerbler, Ravbar, 2013).

Gorenjsko označuje kakovostno naravno okolje z velikimi količinami ustrezne pitne vode iz prodnih vodonosnikov in izvirov ter velikimi možnostmi za rabo obnovljivih virov energije s poudarkom na uporabi lesne biomase, saj se regija uvršča med najbolj gozdnate v Sloveniji (Plut, 2013). Pomemben razvojni potencial Gorenjske so tudi prebivalci, posebno 
ob nadpovprečni rodnosti relativno visok delež oseb, mlajših od 25 let (Pelc, Dolenc, 2013). Omenjeni avtorji opozarjajo na nujnost sledenja načelom sonaravnega/trajnostnega regionalnega razvoja kot pristop za ustrezno rabo endogenih razvojnih potencialov v prihodnosti, predvsem na obsežnih zavarovanih območjih (npr. Plut, 2013; Ravbar, Kovačič, 2013), pa tudi na kmetijskih zemljiščih, ki »... so v regiji izjemno omejen naravni vir ...«, a na njih prevladujejo ekstenzivne kmetijske rabe (Cunder, Lampič, 2013, str. 175).

$\mathrm{Na}$ podlagi ocene relativnega razvojnega položaja Gorenjske statistične regije, pripravljene s pomočjo sistema kazalcev za merjenje regionalne strukture, in ob upoštevanju izkušenj drugih avtorjev, ki z drugačnimi teoretično-metodološkimi pristopi pritrjujejo našim ugotovitvam, predlagamo nekatera priporočila za razvojno usmeritev Gorenjske. Razvoj naj temelji na trajnostni rabi endogenih razvojnih potencialov, posebno na področju kakovostnega 'človeškega kapitala'. Ob hkratnem relativno visokem deležu sredstev za raziskave in razvoj naj Gorenjska razvija na znanju in kreativnosti temelječe gospodarske dejavnosti. Na zavarovanih območjih naj imajo pri razvoju prednost sonaravne oblike turizma in kmetijstva. Regija bo tako ohranila privlačnost bivalnega okolja ter okrepila privlačnost delovnega okolja.

\section{Viri in literatura}

Braudel, F., 1991. Čas sveta. Materialna civilizacija, ekonomija in kapitalizem, XV.XVIII. stoletje. Ljubljana, ŠKUC, Filozofska fakulteta, 537 str.

Cestna vozila konec leta (31.12.) glede na vrsto vozila in statistično regijo, Slovenija, letno. 2013. Ljubljana, Statistični urad Republike Slovenije. URL: http://pxweb. stat.si/pxweb/Dialog/varval.asp?ma=2222104S\&ti=Cestna+vozila+konec+leta $+\% 2831.12 . \% 29+$ glede + na + vrsto + vozila + in + statisti $\%$ E 8 no + regijo $\% 2 C+$ Slovenija\%2C+letno\&path=../Database/Ekonomsko/22_transport/08_22221_reg_cestna_ vozila/\&lang=2 (Citirano 16. 1. 2014).

Cunder, T., Lampič, B., 2013. Strukturne spremembe in trajnostna naravnanost kmetijstva na Gorenjskem. V: Rogelj, B., Potočnik Slavič, I., Mrak, I. (ur.). Gorenjska v obdobju glokalizacije. Ljubljana, Znanstvena založba Filozofske fakultete, str. 175-190.

Černe, A., Kušar, S., 2006. Regional, spatial and environmental indicators for an assessment of regional development, structure and potentials. Dela, 26, str. 27-41. DOI: $10.4312 /$ dela.26.3.27-41

Černe, A., Gulič, P., Kušar, S., 2004: Proposal for the enlistment of ideal/optimal indicators for monitoring spatial development in states and regions included in the „CONSPACE“ project. CONSPACE - PP5 - WP2 harmonisation of tools, data and procedures and monitoring of spatial development. Elaborat. Ljubljana, University of Ljubljana, Faculty of Arts, Department of Geography, 44 str.

Gabrovec, M., Bole, D., 2013. Rast prometnih površin na Gorenjskem v zadnjih 200 letih. V: Rogelj, B., Potočnik Slavič, I., Mrak, I. (ur.). Gorenjska v obdobju glokalizacije. Ljubljana, Znanstvena založba Filozofske fakultete, str. 99-110.

Geoportal ARSO. Agencija Republike Slovenije za okolje. 2013. URL: http://gis.arso. gov.si/geoportal/catalog/main/home.page (Citirano 29. 5. 2013). 
GERK. 2011. Ljubljana, Ministrstvo za kmetijstvo, gozdarstvo in prehrano. URL: http:// rkg.gov.si/GERK (Citirano 26. 3. 2011).

Gorenjska v obdobju glokalizacije. 2013. Rogelj, B., Potočnik Slavič, I., Mrak, I. (ur.). Ljubljana, Znanstvena založba Filozofske fakultete, 365 str.

Kavaš, D., 2010. Expert evaluation network delivering policy analysis on the performance of cohesion policy 2007-2013. Task 2: Country report on achievements of cohesion policy Slovenia. Final version. Ljubljana, Institute for Economic Research, 25 str. URL: http://ec.europa.eu/regional_policy/sources/docgener/evaluation/pdf/ eval2007/country_reports/slovenia.pdf(Citirano 25.2. 2014).

Kazalci okolja v Sloveniji. 2011. Agencija Republike Slovenije za okolje. URL: http:// kazalci.arso.gov.si/?data=indicator\&ind_id=462 (Citirano 10.5.2013).

Kazalniki blaginje v Sloveniji. 2014. URL: http://www.kazalniki-blaginje.gov.si (Citirano 28. 5. 2014).

Kerbler, B., Ravbar, N., 2013. Suburbanizacija na območju Udin boršta in potreba po spremljanju vplivov na okolje. V: Rogelj, B., Potočnik Slavič, I., Mrak, I. (ur.). Gorenjska v obdobju glokalizacije. Ljubljana, Znanstvena založba Filozofske fakultete, str. 141-150.

Kozina, J., 2013. Prostorska razmestitev prebivalcev z ustvarjalnim poklicem na Gorenjskem. V: Rogelj, B., Potočnik Slavič, I., Mrak, I. (ur.). Gorenjska v obdobju glokalizacije. Ljubljana, Znanstvena založba Filozofske fakultete, str. 227-238.

Kušar, S., Pichler-Milanović, N., 2010. Ljubljana in the system of settlements and centres. V: Krevs, M., Djordjević, D., Pichler-Milanović, N. (ur.). Challenges of spatial development of Ljubljana and Belgrade (Zbirka GeograFF, 8). Ljubljana, Znanstvena založba Filozofske fakultete, str. 55-69.

Milanović, B., 2006. Global income inequality: a review. World economics, 7, 1, str. 131-157.

NSRO: Nacionalni strateški referenčni okvir. 2008. Služba Vlade Republike Slovenije za lokalno samoupravo in regionalno politiko, 191 str. URL: http://www.eu-skladi.si/ ostalo/operativni-programi/nsro2007-2013.pdf (Citirano 28. 5. 2014).

Pečar, J., 2012. Bruto domači proizvod - regionalni pregled. Delovni zvezki Urada za makroekonomske analize in razvoj, 21, 5, 43 str. URL: http://www.umar.gov.si/publikacije/single/publikacija/zapisi/janja_pecar_bruto_domaci_proizvod_regionalni_ pregled (Citirano 25. 2. 2014).

Pečar, J., Kavaš, D., 2006. Metodologija izračuna indeksa razvojne ogroženosti za obdobje od 2007 do 2013. Delovni zvezki Urada Republike Slovenije za makroekonomske analize in razvoj, 15, 6, 62 str. URL: http://www.umar.gov.si/publikacije/single/ publikacija/zapisi/delovni_zvezek_062006 (Citirano 25. 2. 2014).

Pelc, S., Dolenc, D., 2013. Temeljne prebivalstvene značilnosti Gorenjske v prvem desetletju 21. stoletja. V: Rogelj, B., Potočnik Slavič, I., Mrak, I. (ur.). Gorenjska v obdobju glokalizacije. Ljubljana, Znanstvena založba Filozofske fakultete, str. 191-212.

Pierre-Noël, G., 2006. Neenakost v svetu. Ekonomija sodobnega sveta. Ljubljana, Založba /*cf., 299 str. 
Plut, D., 2013. Vodna, energetska ter prehranska samooskrba Slovenije in Gorenjske možnost ali utopija? V: Rogelj, B., Potočnik Slavič, I., Mrak, I. (ur.). Gorenjska v obdobju glokalizacije. Ljubljana, Znanstvena založba Filozofske fakultete, str. 151-164.

Podatkovne baze o poplavnih območjih, erozijskih območjih in območjih zemeljskih plazov ter o območjih snežnih plazov. Arhiv Oddelka za geografijo. 2011.

Popis kmetijskih gospodarstev 2010. 2011. Ljubljana, Statistični urad Republike Slovenije. URL: http://www.stat.si/popiskmetijstva2010 (Citirano 26. 1. 2014).

Pregled mestnih naselij in naselij mestnih območij, merila za uvrstitev, sedeži občin, podatki o prebivalstvu in delovno aktivnem prebivalstvu, Slovenija, 1. 1. 2009. Ljubljana, Statistični urad Republike Slovenije. URL: www.stat.si/letopis/2009/32_09/32-01-09. xls (Citirano 1. 5. 2013).

Ravbar, N., Kovačič, G., 2013. Viri pitne vode na Gorenjskem: pregled oskrbe z vodo in upravljanje. V: Rogelj, B., Potočnik Slavič, I., Mrak, I. (ur.). Gorenjska v obdobju glokalizacije. Ljubljana, Znanstvena založba Filozofske fakultete, str. 165-174.

Rus, P., Razpotnik Visković, N., Nared, J., 2013. Upravljanje območij z vidika sprememb funkcijskih zaledij centralnih krajev: primer Gorenjske. V: Rogelj, B., Potočnik Slavič, I., Mrak, I. (ur.). Gorenjska v obdobju glokalizacije. Ljubljana, Znanstvena založba Filozofske fakultete, str. 253-268.

Slovenske regije v številkah 2013. 2013. Ljubljana, Statistični urad Republike Slovenije, 76 str. URL: http://www.stat.si/doc/pub/REGIJE-2013.pdf (Citirano 19. 4. 2013).

Statistični urad Republike Slovenije. 2014. URL: http://pxweb.stat.si/pxweb/Dialog/statfile2.asp (Citirano 26. 1. 2014).

Uredba o določitvi obmejnih problemskih območij. 2011. Uradni list RS, 22 (25. 3. 2011). URL: http://www.uradni-list.si/1/objava.jsp?urlid=201122\&stevilka=954 (Citirano 25. 2. 2014).

Zakon o spodbujanju skladnega regionalnega razvoja. 2011. Uradni list RS, 20 (18. 3. 2011). URL: http://www.uradni-list.si/1/content?id=102704 (Citirano 7. 4. 2013).

\section{DEVELOPMENTAL CONDITION OF GORENJSKA STATISTICAL REGION}

\section{Summary}

The presented paper is an attempt how to evaluate relative developmental condition of Gorenjska statistical region on the basis of the system of indicators for demographical and socio-economic structure, settlement network, countryside, quality of living, infrastructure, land use, protected areas, degraded areas and endangered areas. Together with standardization and grading, it indicates some of the developmental opportunities for the region.

The region is ranging in the upper third of statistical regions with the most favourable demographical structure; therefore, region has relatively qualitative human capital and good possibilities for future development. With high natural population increase the human potential for the development will be preserved. 
Gorenjska has been faced with intensive deindustrialization. Despite relatively weak economic strength, the high above average percentage of GDP is used for research and development activities which can be a solid developmental basis and suitable potential for future economic and regional development.

Natural characteristics of the region, relatively early industrialization, settlement structure and good transport accessibility in Ljubljana Basin were the factors of the development of the settlement network and urban pattern. Recently, the process of suburbanization has influenced population density also in suburban areas. In comparison with other statistical regions, the degree of urbanization of Gorenjska region is relatively high, which can have a positive effect on broader regional and local development initiatives.

Protected areas with high natural and cultural value are an important developmental factor for the region. They could be an important developmental potential of the region, if the principles of sustainable regional development will be introduced.

(Translated by the authors) 